\title{
In Vitro Comparison of Biological Effects of Coe-Pak and Reso-Pac Periodontal Dressings
}

\author{
Mahdi Kadkhodazadeh ${ }^{1}$, Zahra Baghani ${ }^{1,2}$, Maryam Torshabi ${ }^{3}$, Bahar Basirat ${ }^{1}$ \\ ${ }^{1}$ Department of Periodontics, School of Dentistry, Shahid Beheshti University of Medical Sciences, Tehran, Iran. \\ ${ }^{2}$ Department of Periodontics, School of Dentistry, Sabzevar University of Medical Sciences, Sabzevar, Iran. \\ ${ }^{3}$ Department of Dental Biomaterials, School of Dentistry, Shahid Beheshti University of Medical sciences, Tehran, Iran.
}

\section{Corresponding Author:}

Zahra Baghani

Department of Periodontics, Dental School

Sabzevar University of Medical Sciences, Sabzevar

Iran

Phone: +98 5144011300-6

Fax: +98 5144011300-6

E-mail: za baghani@yahoo.com

\begin{abstract}
Objectives: The purpose of the present study was to compare the cytotoxicity of Reso-Pac and Coe-Pak periodontal dressing. Material and Methods: According to ISO-10993-12:2012, 1-, 3- and 7-day extracts of the two periodontal dressings were prepared in cell culture medium and exposed to the two cultured cell lines. Cell viability and proliferation at $24 \mathrm{~h}$ and $72 \mathrm{~h}$ following exposure were evaluated using quantitative MTT assay.

Results: The results showed a significant $(\mathrm{P}<0.05)$ reduction in the viability of cells exposed to the 3- and 7-day Coe-Pak extracts at $24 \mathrm{~h}$ and $72 \mathrm{~h}$ compared to the control group (no exposure to the extract). Reso-Pac extracts slightly decreased cell viability compared to the control group. Understudy materials showed greater cytotoxicity against human osteoblast-like compared to the human gingival fibroblast cells. No significant $(\mathrm{P}>0.05)$ difference was found in the viability of cells exposed to undiluted (100\%) one-day extract and diluted (50\%) extract of both understudy materials at $24 \mathrm{~h}$ and $72 \mathrm{~h}$ after exposure. Conclusions: Based on the results, Reso-Pac periodontal dressing has less cytotoxicity than Coe-Pak.
\end{abstract}

Keywords: fibroblasts; materials testing; osteoblasts; periodontal dressings.

\author{
Accepted for publication: 29 March 2017 \\ To cite this article: \\ Kadkhodazadeh M, Baghani Z, Torshabi M, Basirat B. \\ In Vitro Comparison of Biological Effects of Coe-Pak and Reso-Pac Periodontal Dressings \\ J Oral Maxillofac Res 2017;8(1):e3 \\ URL: http://www.ejomr.org/JOMR/archives/2017/1/e3/v8n1e3.pdf \\ doi: $10.5037 /$ jomr.2017.8103
}




\section{INTRODUCTION}

Periodontal dressings are among the commonly used products by periodontists. Periodontal dressing was first introduced by Ward in 1923 [1]; he recommended its use following periodontal surgery. At present, periodontal dressings are extensively used for various purposes; however, their use following periodontal surgery is a matter of debate [2]. Several advantages have been described for periodontal dressings recommending their application following periodontal surgery including wound protection from mechanical trauma, wound stabilization $[\underline{3}, \underline{4}]$, patient comfort, favourable adaptation to the underlying tissue, prevention of post-surgical bleeding or infection, decreased tooth hypersensitivity, clot protection from the loads applied during mastication and speech, prevention of gingival separation from the root []], prevention of coronal displacement of an apically repositioned flap and providing extra support for free gingival grafts [6] during the tissue healing phase. In general, periodontal dressings are divided into 3 groups:

1. Dressings containing zinc oxide eugenol (Ward's Wondr Pak).

2. Dressings containing zinc oxide without eugenol (Periocare, Coe-Pak, Vac-Pac, Septo-Pac).

3. Dressings without zinc oxide and eugenol (cellulose-based dressings i.e. Mucotect and Reso-Pac) and light-cured resin-based dressings (i.e. Barricaid).

Several human and animal cell lines have been used for the assessment of the cytotoxic effects of periodontal dressings [7-9]. Eugenol-containing products can cause tissue inflammation, necrosis and allergic reactions and can subsequently delay the process of healing [10-13]. Thus, the application of these products has been limited. Coe-Pak is the most commonly used product from the second group of periodontal dressings. It is based on the reaction between a metallic oxide and fatty acid and is supplied in two tubes. The two pastes are mixed until a uniform colour is obtained and it is then applied [14]. Compared to group 1, this product has less cytotoxicity [15]. However, rosin is among the main constituents of Coe-Pak comprising of resin acids by $70 \%$. It induces a strong dosedependent reaction in polymorphonuclear leukocytes (PMN) and human gingival fibroblasts under in vitro conditions. This effect decreases by an increase in zinc concentration. Pure acids released from natural rosin are the main toxic compounds [16]. Induced contact allergy and skin dermatitis due to exposure to rosin-containing products have been confirmed by several researchers $[17,18]$. Published data regarding the biocompatibility of cellulose-based dressings are scarce. Reso-Pac is supplied in the form of a hydrophilic paste. It does not require mixing or preparation before use and remains in place for more than $30 \mathrm{~h}$. It gradually dissolves in the saliva and does not need removal.

Table 1 shows quantitative data provided by the manufacturer regarding the composition of the 2 understudy materials.

Many dental products cause allergic reactions in the oral cavity. But, these reactions in the oral cavity are less frequent than on the skin due to the presence of saliva and highly vascularized oral mucosa. Some in vitro tests have been recommended for the assessment of the cytotoxicity of periodontal dressings in the cell culture medium [19]. Implantation has also been suggested for the assessment of local cytotoxicity $[\underline{20}, \underline{21}]$. Although periodontal dressings are in contact with the tissue for only a limited period of time, they need to have the lowest tissue irritation possible. Therefore, this study was undertaken to compare the cytotoxic effects of Coe-Pak (the most commonly used dressing of the $2^{\text {nd }}$ group) and Reso-Pac (cellulose-based dressing) and assess their biocompatibility in the cell culture medium at different time points.

Table 1. Composition of understudy periodontal dressings according to the manufacturing company

\begin{tabular}{l|l|c}
\hline \multicolumn{1}{c|}{ Materials } & \multicolumn{1}{c|}{ Composition } & \multicolumn{1}{c}{$\begin{array}{c}\text { Manufacturing } \\
\text { company }\end{array}$} \\
\hline \multirow{2}{*}{$\begin{array}{l}\text { Coe-Pak } \\
\text { Paste-Paste } \\
\text { Chemical cure }\end{array}$} & $\begin{array}{l}\text { Base: rosin, cellulose, natural gums and wax, liquid coconut fatty } \\
\text { acid, chlorothymol, zinc acetate, denatured alcohol methanol, } \\
\text { petrolatum, lorothidol. }\end{array}$ & GC, USA \\
\cline { 2 - 3 } & $\begin{array}{l}\text { Accelerator: zinc oxide, vegetable oil, mineral oil chlorothymol, } \\
\text { silica, magnesium oxide, synthetic resin, coumarin. }\end{array}$ & \\
\hline $\begin{array}{l}\text { Reso-Pac } \\
\text { Paste }\end{array}$ & $\begin{array}{l}\text { Carboxymethyl cellulose, polyvinyl acetate, ethyl alcohol, myrrh, } \\
\text { Hydrophilic } \\
\text { Hager \& Werken GmbH \& Co. KG }\end{array}$ & $\begin{array}{l}\text { Hager \& Werken } \\
\text { GmbH \& Co. KG }\end{array}$ \\
\hline
\end{tabular}




\section{MATERIAL AND METHODS}

This study evaluated and compared the effects of Reso-Pac (Hager \& Werken GmbH \& Co. KG, Germany) and Coe-Pak (GC, USA) on the viability and proliferation of human gingival fibroblast (HGF1-PI1, NCBI: C165, Pasteur, Tehran, Iran) and human osteoblast-like (Saos-2, NCBI: C453, Pasteur, Tehran, Iran) cell lines using quantitative MTT assay compared to the control group (Table 1).

\section{Preparation of samples and extracts}

Samples were prepared according to the ISO-10993$12: 2012$. From each of the studied materials, 6 specimens were fabricated measuring $2 \times 8 \mathrm{~mm}$ according to the manufacturers' instructions under completely aseptic conditions. The specimens were exposed to UV light for a few minutes for sterilization. Each specimen was transferred to a sterile cell-culture 6-well plate and $2.5 \mathrm{ml}$ of the Dulbecco's modifed Eagle's medium (DMEM- Gibco, USA) containing $1 \%$ penicillin-streptomycin (Gibco, USA) was added to each well. Plates were stored in an incubator (Memmert, Germany) at $37{ }^{\circ} \mathrm{C}, 5 \% \mathrm{CO}_{2}$ and $95 \%$ humidity and the extract was collected at one, 3 and 7 days.

\section{Cell culture}

One day prior to the onset of experiment, 1500 cells of the two understudy cell lines were cultured in $100 \mu \mathrm{l}$ of the complete culture medium in each well of a 96-well plate (SPL, Korea) and incubated for $24 \mathrm{~h}$. At the day of experiment, the culture medium of each well was removed and replaced with the respective extracts after adding 10\% Fetal bovine serum (FBS - Gibco, USA). Complete culture medium with no extract was added to the cells as negative control group (no cytotoxicity, $100 \%$ viability). Sterile distilled water was added to the cells as positive control group (severe cytotoxicity, viability $<10 \%)$. The plates were then stored again in an incubator.

\section{Assessment of cell viability and proliferation using MTT assay}

Quantitative MTT (dimethyl-thiazoldiphenyltetrazoliumbromide) assay was used to assess the viability and proliferation of cells exposed to the dressing extracts. MTT assay was performed according to ISO-10993-5:2009. At $24 \mathrm{~h}$ and $72 \mathrm{~h}$ after exposure, the 96-well plates were removed from the incubator and the medium in each plate was extracted. Cells were washed with sterile phosphate buffered saline (PBS) solution (Gibco, USA) and $100 \mu \mathrm{l}$ of the serum- and antibiotic-free culture medium containing 10\% MTT dye (Sigma, Germany) was added to each well. The plates were then stored in an incubator at $37{ }^{\circ} \mathrm{C}$ for $3 \mathrm{~h}$ at $98 \%$ humidity and $5 \% \mathrm{CO}_{2}$. During this time period, succinate dehydrogenase present in the mitochondria of healthy and metabolically active cells reduces MTT, a yellow tetrazole, to insoluble purple formazan crystals. After completion of the incubation period, the medium of cells was gently removed and $100 \mu$ of dimethyl sulfoxide solvent (DMSO - Gibco, USA) was added to each well to dissolve insoluble formazan crystals. The absorbance (OD) of the coloured (purple) solution for each specimen has a direct correlation with the number of metabolically active cells. OD was measured by ELISA Reader (Anthos 2020, Austria) at $570 \mathrm{~nm}$ wavelength with a $620 \mathrm{~nm}$ reference filter. The percentage of cell viability was calculated by dividing the mean absorbance of each group by the mean absorbance of the negative control group multiplied by 100 (Tables 2 and 3; Figures 1 and 2).

\section{Statistical analysis}

The assay was repeated at two different time points and the mean value (obtained by the quantitative MTT assay) was calculated, compared with the negative control group (regular culture medium alone, no cytotoxicity, $100 \%$ viability) and the percentage of increase or decrease in cell viability and proliferation was determined. Data were presented as mean standard deviation (SD).

Table 2. Percentage of viability of human gingival fibroblast cells at $24 \mathrm{~h}$ and 72 hours after exposure to 1-, 3- and 7-day extracts of Coe-Pak and Reso-Pac compared to the NC group

\begin{tabular}{|c|c|c|c|c|c|c|c|c|}
\hline \multirow{3}{*}{ Time } & \multicolumn{8}{|c|}{$\%$ viability (Mean [SD]) } \\
\hline & \multirow{2}{*}{ NC } & \multicolumn{3}{|c|}{ Coe-Pak extracts } & \multicolumn{3}{|c|}{ Reso-Pac extracts } & \multirow{2}{*}{ PC } \\
\hline & & Day 1 & Day 3 & Day 7 & Day 1 & Day 3 & Day 7 & \\
\hline $24 \mathrm{~h}$ & $100(4.1)$ & $92.9(3.5)$ & $11.5(0.7)$ & $10.5(1)$ & $110.5(0.6)$ & $92.5(4.8)$ & $71.3(3.1)$ & $10.1(0.6)$ \\
\hline $72 \mathrm{~h}$ & $100(0.6)$ & $93.6(5.8)$ & $10(0.5)$ & $12.2(0.2)$ & $114.7(3.5)$ & $96.8(3)$ & $83.6(2.5)$ & $5.4(0.4)$ \\
\hline
\end{tabular}

$\mathrm{SD}=$ standard deviation; $\mathrm{NC}=$ negative control (regular culture medium alone; without extracts, no cytotoxicity, $100 \%$ viability); PC = positive control (cytotoxic, viability $\leq 10 \%$ ). 
Table 3. Percentage of viability of Saos- 2 cells at $24 \mathrm{~h}$ and 72 hours after exposure to 1-, 3- and 7-day extracts of Coe-Pak and Reso-Pac

\begin{tabular}{c|c|c|c|c|c|c|c|c}
\hline \multirow{2}{*}{ Time } & \multicolumn{7}{|c}{ \% viability (Mean [SD]) } & \multicolumn{3}{c}{ Reso-Pac extracts } \\
\cline { 2 - 8 } & \multirow{2}{*}{ NC } & \multicolumn{3}{|c|}{ Coe-Pak extracts } & \multicolumn{3}{c}{ PC } \\
\cline { 2 - 9 } & & Day 1 & Day 3 & Day 7 & Day 1 & Day 3 & Day 7 & \\
\hline $\mathbf{2 4} \mathbf{~ h}$ & $100(1.9)$ & $61.5(2.7)$ & $5(0.9)$ & $3.8(0.2)$ & $85.6(4.8)$ & $93.4(3.4)$ & $71.4(4.9)$ & $4.4(0.3)$ \\
\hline $\mathbf{7 2} \mathbf{~ h}$ & $100(0.7)$ & $65.8(0.9)$ & $3.1(0.1)$ & $3.2(0.6)$ & $90.5(2.5)$ & $92.7(3)$ & $73(6)$ & $3.9(0.9)$ \\
\hline
\end{tabular}

$\mathrm{SD}=$ standard deviation; $\mathrm{NC}=$ negative control (regular culture medium alone; without extracts, no cytotoxicity, $100 \%$ viability); PC = positive control (cytotoxic, viability $\leq 10 \%$ ).

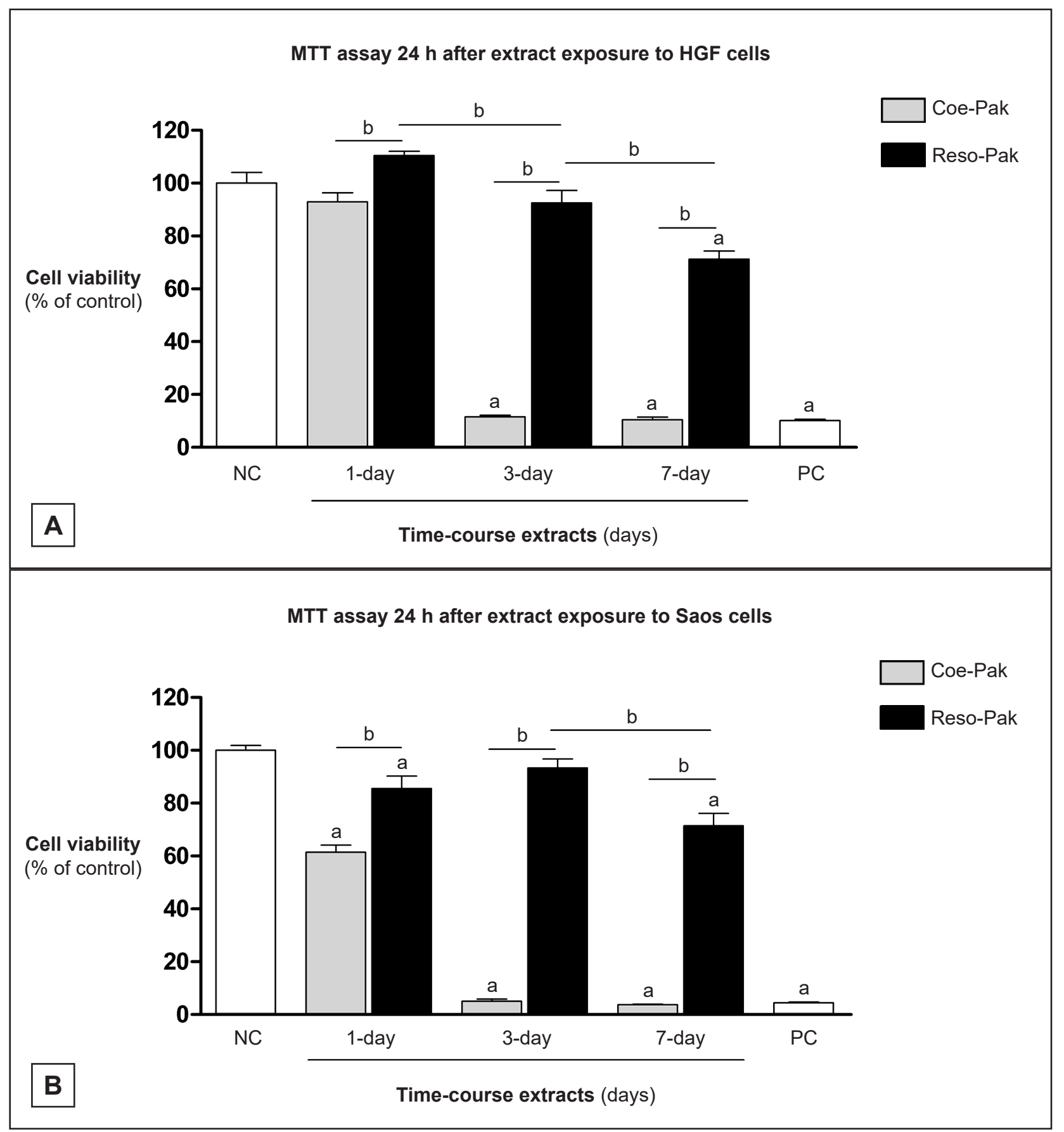

Figure 1. The effect of 1-, 3- and 7-day extracts of Coe-Pak and Reso-Pac on cell after $24 \mathrm{~h}$ exposure compared to the NC group and one another: $\mathrm{A}=$ human gingival fibroblast (HGF); $\mathrm{B}=$ human osteoblast-like cell (Saos-2).

${ }^{a}$ Statistically significant difference with NC group at the level $\mathrm{P}<0.05$ (One-way ANOVA, Tukey's post-hoc test).

${ }^{\mathrm{b} S t a t i s t i c a l l y ~ s i g n i f i c a n t ~ d i f f e r e n c e ~ b e t w e e n ~ t h e ~ g r o u p s ~ a t ~ t h e ~ l e v e l ~} \mathrm{P}<0.05$ (One-way ANOVA, Tukey's post-hoc test).

$\mathrm{NC}=$ negative control (no cytotoxicity, $100 \%$ viability); $\mathrm{PC}=$ positive control (cytotoxicity, viability $\leq 10 \%$ ). 


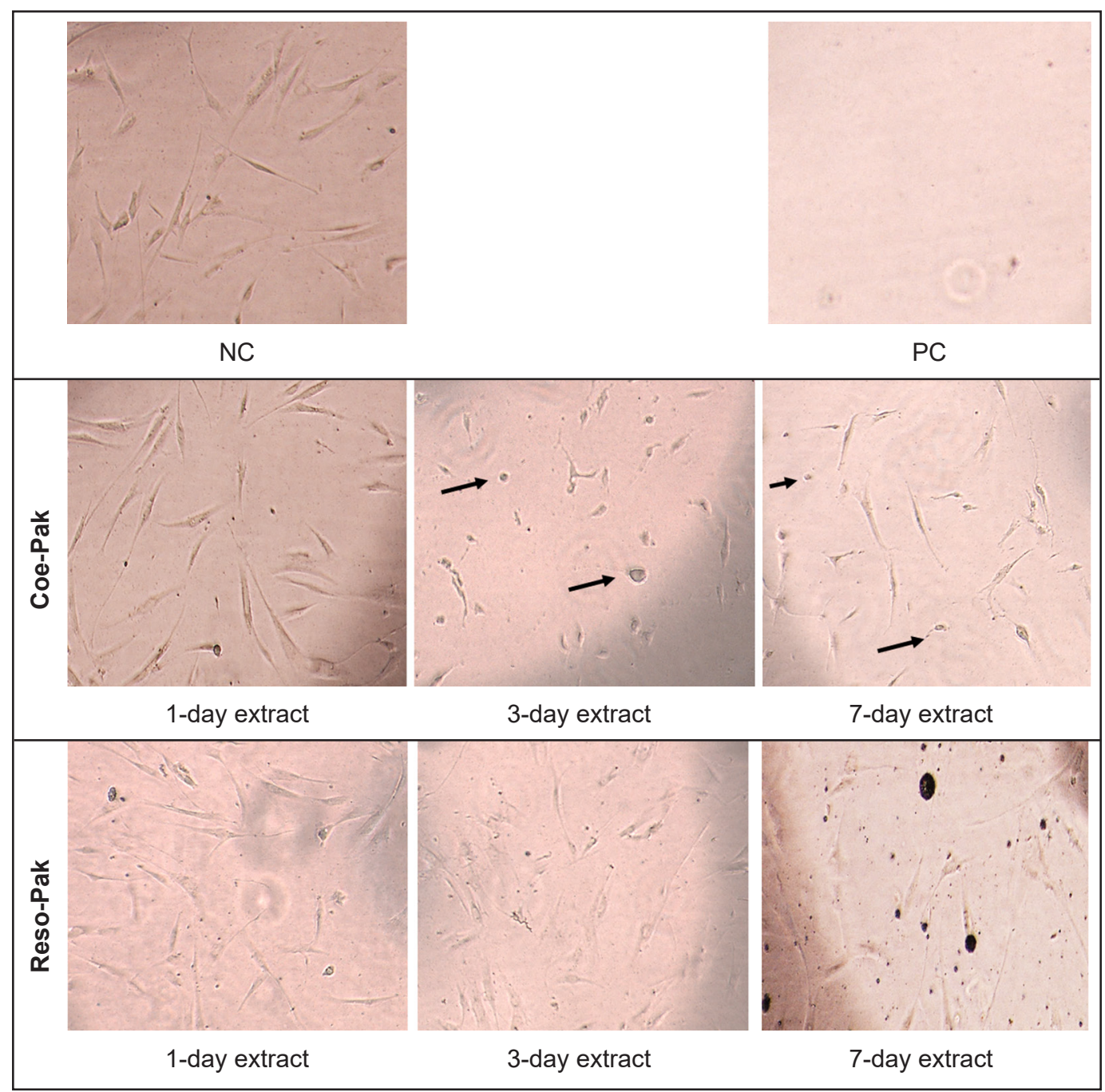

Figure 2. Qualitative morphological assessment of human gingival fibroblast cells at $24 \mathrm{~h}$ after Coe-Pak and Reso-Pac time-course extracts exposure.

$\mathrm{NC}=$ negative control (no cytotoxicity); $\mathrm{PC}=$ positive control (severe cytotoxicity).

Apoptotic (dead) cells are marked with arrows.

GraphPad prism v6.01 software and one-way ANOVA method (followed by Tukey's post hoc test for pairwise comparison of groups) were used for statistical analysis. $\mathrm{P}<0.05$ was considered statistically significant.

\section{RESULTS}

\section{Cytotoxic effect of periodontal dressings on HGF cells}

HGF cells were exposed to the 1-, 3- and 7-day extracts of Coe-Pak and Reso-Pac and the percentage of cell viability was evaluated at $24 \mathrm{~h}$ and $72 \mathrm{~h}$ after exposure (Table 2, Figures 1A and 3).

At 3- and 7-day Coe-Pak extracts significantly decreased HGF cell viability compared to the negative control group (dose-dependent cytotoxicity) and the difference in this respect with Reso-Pac was statistically significant $(\mathrm{P}<0.05)$. However, 1-day Coe-Pak extract had no significant $(\mathrm{P}>0.05)$ effect on cell viability compared to the negative control (Figure 1A). For Reso-Pac, the significant reduction in HGF cell viability (compared to the negative control) only was seen after 7-day exposure $(\mathrm{P}<0.05)$ (Figure 1A). At $72 \mathrm{~h}$, the difference between the 3-day and 7-day extracts of Reso-Pac and Coe-Pak was statistically significant $(\mathrm{P}<0.05)$.

Comparison of the effects of extracts on HGF cells at $24 \mathrm{~h}$ and $72 \mathrm{~h}$ revealed that no significant differences were seen between $24 \mathrm{~h}$ and $72 \mathrm{~h}$ exposure in all experimental groups $(\mathrm{P}<0.05)$ (no time-dependent cytotoxicity) (Figure 4A).

Morphological assessment of HGF cells at $24 \mathrm{~h}$ after Coe-pak and Reso-pac time-course extracts exposure has shown in Figure 2. 


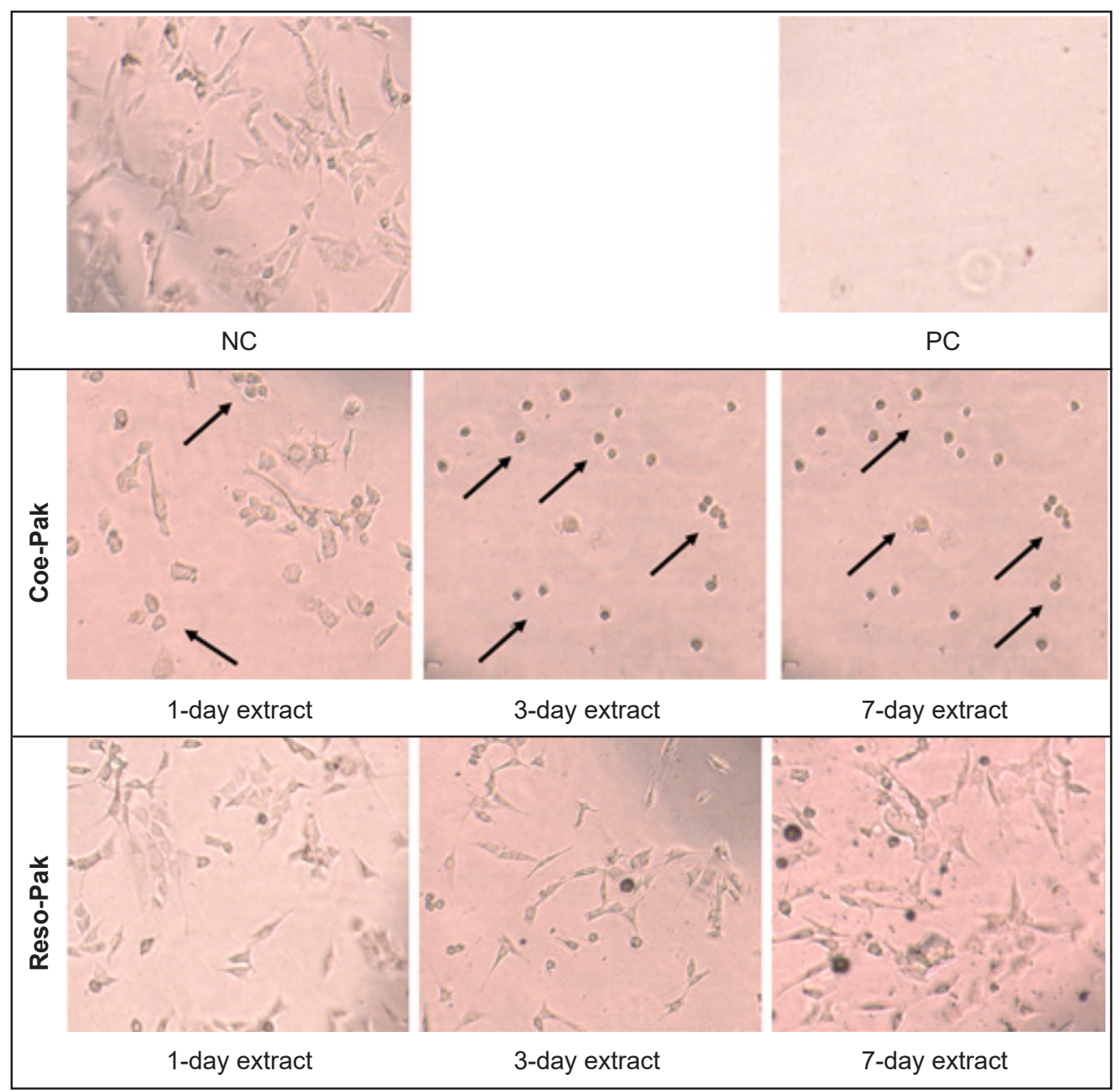

Figure 3. Qualitative morphological assessment of human osteoblast-like cell at $24 \mathrm{~h}$ after Coe-Pak and Reso-Pac time-course extracts exposure.

$\mathrm{NC}=$ negative control (no cytotoxicity); $\mathrm{PC}=$ positive control (severe cytotoxicity).

Apoptotic (dead) cells are marked with arrows.

Apoptotic (round dead cells) was significantly seen more in Coe-Pak treated cells than in Reso-pac treated cells.

No significant difference was found $(\mathrm{P}>0.05)$ in the viability of HGF cells exposed to 1-day undiluted extract $(100 \%)$ and diluted extract $(50 \%)$ of both understudy dressing materials (Figure 5).

\section{Cytotoxic effect of periodontal dressings on Saos-2 cells}

Saos-2 cells were also exposed to Coe-Pak and ResoPac extracts and the percentage of cell viability at $24 \mathrm{~h}$ and $72 \mathrm{~h}$ was evaluated (Table 3, Figures 1B and $4 \mathrm{~B})$.

At $24 \mathrm{~h}, 3-$ and 7-day exposure to Coe-Pak extracts were significantly $(\mathrm{P}<0.05)$ toxic for Saos-2 cells (reduction in cell viability $>30 \%$ ); whereas, Reso-Pac extracts slightly decreased cell viability which was significant only at 7 -day time point (but still $>70 \%$ )
$(\mathrm{P}<0.05)$ (Figure 1B).

At $72 \mathrm{~h}$ after the exposure of Saos-2 cells to 1-, 3and 7-day extracts of the two periodontal dressings, it was observed that 1-, 3- and 7-day extracts of CoePak significantly decreased cell viability and this difference compared to Reso-Pac was statistically significant $(\mathrm{P}<0.05)$. On the other hand, 1-, 3- and 7-day extracts of Reso-Pac decreased cell viability as well but compared to the negative control group, these reductions were not significant $(P>0.05)$ (Figure 4B). Comparison of the effects of extracts on Saos-2 cells at $24 \mathrm{~h}$ and $72 \mathrm{~h}$ revealed that no significant differences were seen between $24 \mathrm{~h}$ and $72 \mathrm{~h}$ exposure in all experimental groups $(\mathrm{P}<0.05)$ (no timedependent cytotoxicity) (Figure 4B).

Qualitative morphological assessment of Saos-2 cells at $24 \mathrm{~h}$ after Coe-pak and Reso-pac time-course extracts exposure has shown in Figure 3. Apoptotic (round dead cells) was significantly seen more in Coe-Pak treated cells than in Reso-Pac treated cells. 

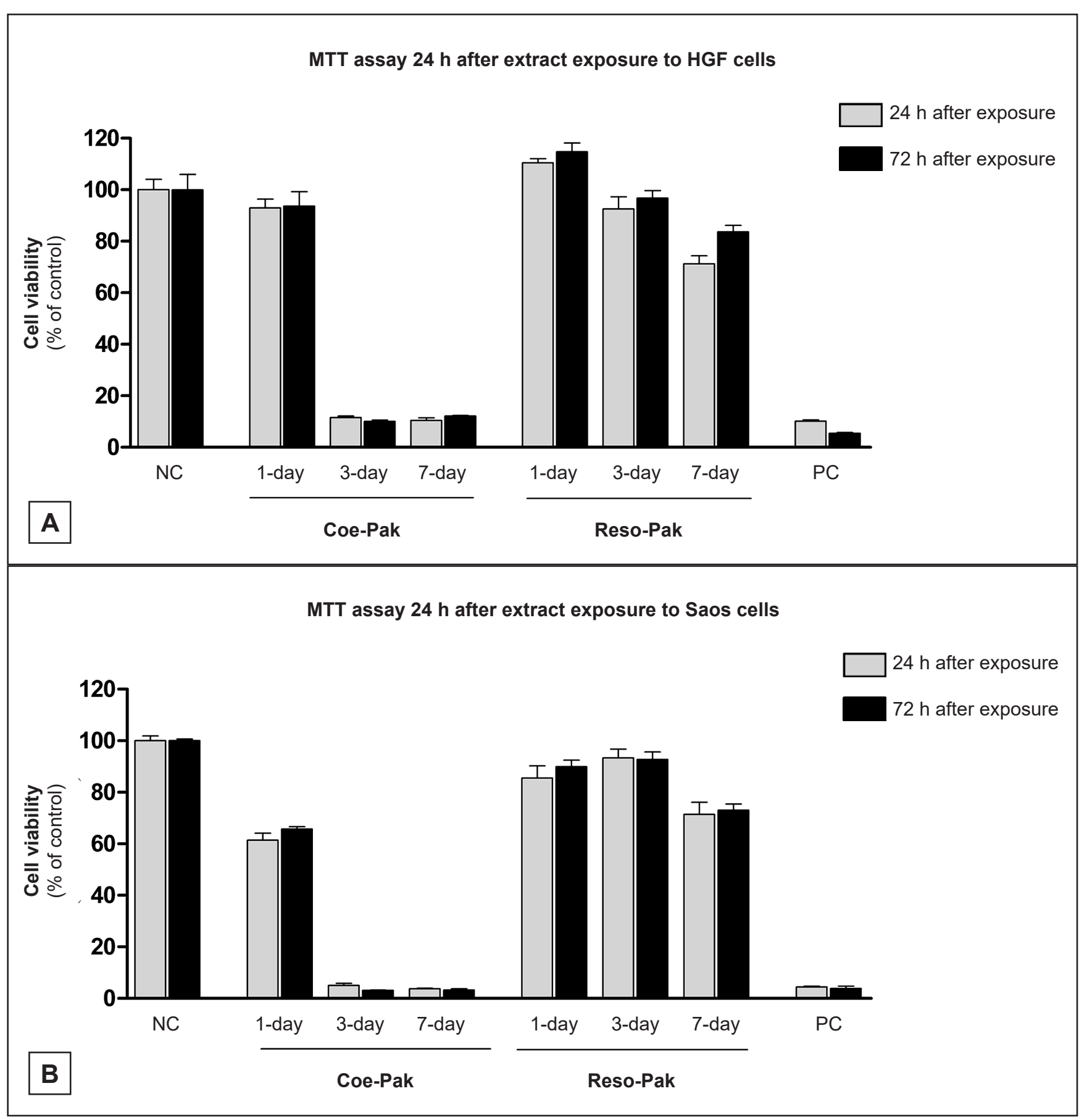

Figure 4. Comparison effect of exposure-time (24 vs 72 h) of 1-, 3- and 7-day extracts of Coe-Pak and Reso-Pac on cell viability and one another: $\mathrm{A}=$ human gingival fibroblast (HGF); $\mathrm{B}=$ human osteoblast-like cell (Saos-2).

No significant differences were seen between $24 \mathrm{~h}$ and $72 \mathrm{~h}$ exposure in all experimental groups $(\mathrm{P}<0.05)$ (no time-dependent cytotoxicity). $\mathrm{NC}=$ negative control (no cytotoxicity, $100 \%$ viability); $\mathrm{PC}=$ positive control (cytotoxicity, viability $\leq 10 \%$ ).

Also, the number of dead Coe-Pak treated cells was seen more in Saos-2 cells than in HGF cells (Figure 2 and 3).

As seen in Figure 5, no significant difference was found in the viability of Saos- 2 cells exposed to oneday undiluted extract $(100 \%)$ and diluted extract $(50 \%)$ of Reso-pac. Interestingly, diluted Coe-Pak extract had less cytotoxic effect $(\sim 30 \%$ increase in cell viability compared to undiluted extract) on Saos-2 cells $(\mathrm{P}<0.05)$.

\section{DISCUSSION}

Periodontal dressings are intended to protect the wound after periodontal surgery to prevent any delay in the process of wound healing. Clearly, periodontal dressings should meet the required criteria for wound healing and must not be toxic to the periodontal tissue; because if so, the process of wound healing will be delayed. Evaluation of 


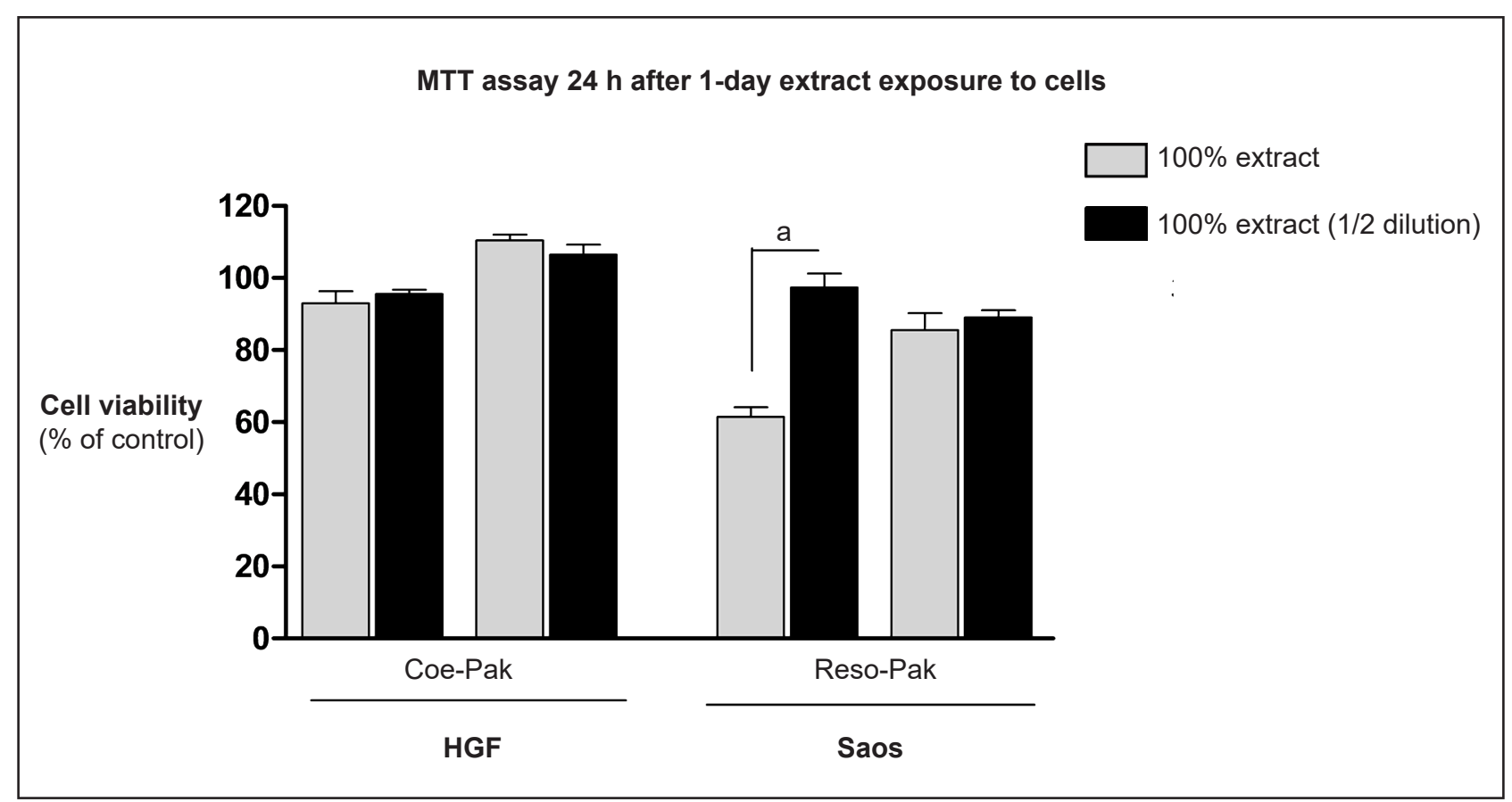

Figure 5. Comparison effect of dilution factor on cell viability at $24 \mathrm{~h}$ after exposure to 1-day undiluted (100\%) and 1:2 diluted (50\%) extracts of Coe-Pak and Reso-Pac.

aStatistically significant difference between the groups at the level $\mathrm{P}<0.05$ (One-way ANOVA, Tukey's post-hoc test).

Only one group showed a significant reduction in cytotoxicity (increased viability) due to dilution.

HGF = human gingival fibroblast; Saos = human osteoblast-like cell.

the effects of periodontal dressings on gingival healing is an interesting topic of research for periodontists. Evidence shows that eugenolcontaining dressings delay the process of healing [22], cause allergic reactions [11] and prevent fibroblast proliferation [7]. Several in vivo and in vitro studies $[\underline{12}, \underline{23-28,} \underline{30}]$ have investigated the cytotoxicity of periodontal dressings. Some in vitro tests have been introduced for cytotoxicity testing of materials with the use of cell culture medium [31]. Screening for local toxicity of products has also been carried out by implantation tests to further assess the biological properties of materials $[\underline{18}, \underline{21}, \underline{32-34}]$.

Several primary cell culture media and cell types have shown different responses to periodontal dressings [34]. Mouse fibroblasts (3T3), L929 and HeLa cells, human epithelial cells, human gingival fibroblasts and leukocytes have been used for this purpose $[\underline{7}, \underline{12}$, 35-37].

Presently, assessment of diverse viability has been suggested for testing the cytotoxicity of different materials against mammalian cells. In vitro assessment of colony formation is the most relevant technique for estimation of cytotoxicity [38].

In our study, HGF (fibroblast) and Saos-2 (osteoblastlike) cells were evaluated for the assessment of cytotoxicity of Coe-Pak and Reso-Pac in cell culture medium (Table 1); the effects of 1-, 3- and 7-day extracts of dressings were evaluated on HGF cell culture medium at $24 \mathrm{~h}$ and $72 \mathrm{~h}$. The 3- and 7-day extracts of Coe-Pak at $24 \mathrm{~h}$ and $72 \mathrm{~h}$ significantly $(\mathrm{P}<0.05)$ decreased cell viability; whereas, this reduction was insignificant $(\mathrm{P}>0.05)$ for ResoPac. The reduction in cell viability due to exposure to 1-day extract of Coe-Pak and Reso-Pac at $24 \mathrm{~h}$ and $72 \mathrm{~h}$ was insignificant $(\mathrm{P}>0.05)$ (Tables 1 and 2). Similar results were obtained for Saos-2 cells indicating that Coe-Pak extract is toxic for HGF and Saos-2 cells as time exceeds $24 \mathrm{~h}$. These results for Saos-2 cells are more significant probably due to the accumulation of toxic materials released from CoePak over time [38]; whereas, Reso-Pac extract had an insignificant effect on HGF and Saos-2 cell cultures.

Sunzel et al. [15] stated that the combination of colophony and zinc in the composition of periodontal dressings may cause cytotoxic effects. On the other hand, rosin is among the main constituents of CoePak that induces a strong dose-dependent cytotoxic reaction in PMN leukocytes and HGF cells (in vitro); however, this effect decreases by increasing the concentration of zinc. It has been noted that pure resin acids released from natural rosin are the main toxic compounds. In our study, the toxicity of CoePak against HGF and Saos-2 cells became more apparent over time; this result was in agreement with the findings of several in vivo and in vitro studies $[7,12,22,24,27,29,30,40]$.

Studies on cellulose-based periodontal dressings 
are scarce. Petelin et al. [28] evaluated the effect of Reso-Pac on fibroblasts and gingival wound healing compared with Barricaid, Fittydent, Mycotect, CoePak and Peripac. They reported that Reso-Pac showed the best epithelialization and vascularity and the least inflammatory reaction during the first 4 days and was reported to be the most suitable periodontal dressing [28]. In the present study, the toxicity of Reso-Pac against HGF and Saos-2 cells was insignificant $(\mathrm{P}>0.05)$; which is in accord with previous studies.

In some previous studies, relative toxicity of the tested materials was significantly variable depending on the type of cells tested [19,39-41]. Geurtsen et al. [38] reported that various primary cells of the human oral tissues such as human pulp fibroblasts and human periodontal ligament fibroblasts are more susceptible to change due to exposure to test materials compared with 3T3 gingival fibroblasts. They stated that no cell line has been recognized to always show hyperor hypo-sensitivity in response to the toxic effects of materials [38]. Moharamzadeh et al. [41] confirmed greater change in cell response of human primary periodontal ligament cells and pulp fibroblasts compared with 3T3 fibroblasts.

Selimović-Dragaš et al. [42] also observed differences in the response of NIH3T3 mouse fibroblasts and UMR-106 osteoblasts for the evaluation of cytotoxicity of resin-modified glass ionomer cements (RMGICs) and the conventional glass ionomer cements (GICs). Similarly, in our study Saos-2 cells showed a more significant response than fibroblasts; which confirms the findings of previous studies indicating different responses of different cell lines to toxic materials.

Polymerized Barricaid is another periodontal dressing approved as a biocompatible material in previous studies. It sets by visible light radiation by a lightcuring unit [37]. In other words, following an accurate lighting protocol and complete polymerization it releases toxic resin compounds. However, it requires more equipment for setting compared to cellulosebased periodontal dressings. This issue can be a limitation for its application compared with Reso-Pac, which is ready to use [43].

\section{CONCLUSIONS}

Based on the results, Reso-Pac cellulose-based periodontal dressing is more biocompatible for human gingival fibroblast cells than Coe-Pak. Coe-Pak has significant cytotoxic effects on human gingival fibroblast and human osteoblast-like cells especially after 3 days of use. Application of some periodontal dressings, despite the described advantages, may delay gingival wound healing following surgery by releasing toxic materials.

\section{ACKNOWLEDGMENTS AND DISCLOSURE STATEMENTS}

The authors declare that there are no financial or other conflicts of interest related to this publication.

\section{REFERENCES}

1. Ward AW. Postoperative Care in the Surgical Treatment of Pyorrhea. J Am Dent Assoc. 1929 Apr 1;16(4):635-40. [doi: 10.14219/jada.archive.1929.0083]

2. Kathariya R, Jain H, Jadhav T. To pack or not to pack: the current status of periodontal dressings. J Appl Biomater Funct Mater. 2015 Jul 4;13(2):e73-86. [Medline: 25363076] [doi: 10.5301/jabfm.5000215]

3. Arnold A, Ariaudo BS, Howard A, Tyrrell BS. Repositioning and increasing the zone of attached gingiva. J Periodontol. 1957 ;28(2):106-10. [doi: 10.1902/jop.1957.28.2.106]

4. Prichard JF. Present state of the interdental denudation procedure. J Periodontol. 1977 Sep;48(9):566-9. [Medline: 333089] [doi: 10.1902/jop.1977.48.9.566]

5. Wikesjö UM, Nilvéus RE, Selvig KA. Significance of early healing events on periodontal repair: a review. J Periodontol. 1992 Mar;63(3):158-65. [Medline: 1593409] [doi: 10.1902/jop.1992.63.3.158]

6. Harpenan LA. Periodontal dressing. In: Hall WB, editors. Critical Decisions in Periodontology, 4th ed. Ontario: BC Decker; 2003. p. 280-1.

7. Eber RM, Shuler CF, Buchanan W, Beck FM, Horton JE. Effect of periodontal dressings on human gingiva fibroblasts in vitro. J Periodontol. 1989 Aug;60(8):429-34. [Medline: 2600752] [doi: 10.1902/jop.1989.60.8.429]

8. Kreth KK, Zimmermann ER, Collings CK. Effect of periodontal dressings on tissue culture cells. J Periodontol. 1966 Jan-Feb;37(1):48-53. [Medline: 5216817] [doi: 10.1902/jop.1966.37.1.48]

9. Rivera-Hidalgo F, Wyan VJ, Horton JE. Effect of soluble extracts from periodontal dressings on human granulocytic leukocytes in vitro. J Periodontol. 1977 May;48(5):267-72. [Medline: 266076] [doi: 10.1902/jop.1977.48.5.267]

10. Barkin ME, Boyd JP, Cohen S. Acute allergic reaction to eugenol. Oral Surg Oral Med Oral Pathol. 1984 Apr;57(4): 441-2. [Medline: $\underline{6584843}$ ] [doi: 10.1016/0030-4220(84)90166-X] 
11. Koch G, Magnusson B, Nyquist G. Contact allergy to medicaments and materials used in dentistry. II. Sensitivity to eugenol and colophony. Odontol Revy. 1971;22(3):275-89. [Medline: 4260919]

12. Haugen E, Hensten-Pettersen A. The sensitizing potential of periodontal dressings. J Dent Res. 1978 Nov-Dec; 57(11-12):950-3. [Medline: 152770] [doi: 10.1177/00220345780570110801]

13. Smith DC. A materialistic look at periodontal packs. Dent Pract Dent Rec. 1970 Apr;20(8):263-7. [Medline: 4988079]

14. Klokkevold PR, Takei HH, Carranza FA. Genral principles of periodontal surgery. In: Newman MG, Takei HH, Klokkevold PR, Carraza FA, editors. Carranza's Clinical Periodontology. 11th ed Philadelphia: Elsevier; 2012. p. 528. [doi: 10.1016/B978-1-4377-0416-7.00054-8]

15. Nezwek RA, Caffesse RG, Bergenholtz A, Nasjleti CE. Connective tissue response to periodontal dressing. J Periodontol. 1980 Sep;51(9):521-9. [Medline: 6932506] [doi: 10.1902/jop.1980.51.9.521]

16. Sunzel B, Söderberg TA, Johansson A, Hallmans G, Gref R. The protective effect of zinc on rosin and resin acid toxicity in human polymorphonuclear leukocytes and human gingival fibroblasts in vitro. J Biomed Mater Res. 1997 Oct;37(1):20-8. [Medline: 9335345] [doi: 10.1002/(SICI)1097-4636(199710)37:13.0.CO:2-L]

17. Hensten-Pettersen A, Jacobsen N. Possible side effects related to dental hygienists' treatment. Acta Odontol Scand. 1994 Jun;52(3):157-61. [Medline: 8091962] [doi: 10.3109/00016359409027590]

18. Isaksson M, Bruze M, Björkner B, Niklasson B. Contact allergy to Duraphat. Scand J Dent Res. 1993 Feb;101(1):49-51. [Medline: 8441896] [doi: 10.1111/j.1600-0722.1993.tb01646.x]

19. Spangberg L, Langeland K. Biologic effects of dental materials. 1. Toxicity of root canal filling materials on HeLa cells in vitro. Oral Surg Oral Med Oral Pathol. 1973 Mar;35(3):402-14. [Medline: 4510611] [doi: 10.1016/0030-4220(73)90078-9]

20. Holland R, de Souza V, Nery MJ, Otoboni Filho JA, Bernabé PF, Dezan Júnior E. Reaction of rat connective tissue to implanted dentin tubes filled with mineral trioxide aggregate or calcium hydroxide. J Endod. 1999 Mar;25(3):161-6. [Medline: 10321179] [doi: 10.1016/S0099-2399(99)80134-4]

21. Roydhouse RH. Implant testing of polymerizing materials. J Biomed Mater Res. 1968 Jun;2(2):265-77. [Medline: 4236788] [doi: 10.1002/jbm.820020209]

22. Kozam G, Mantell GM. The effect of eugenol on oral mucous membranes. J Dent Res. 1978 Nov-Dec;57(11-12):954-7. [Medline: 281340] [doi: 10.1177/00220345780570110901]

23. Haugen E, Mjör IA. Subcutaneous implants for assessments of dental materials with emphasis on periodontal dressings. J Periodontal Res. 1978 May;13(3):262-9. [Medline: 149196] [doi: 10.1111/j.1600-0765.1978.tb00178.x ]

24. Saito CT, Bernabé PF, Okamoto T, Murata SS, Hamata MM, Sundefeld ML. Evaluation of tissue response to periodontal dressings: histological study in tooth sockets of rats. J Appl Oral Sci. 2008 May-Jun;16(3):219-25. [Medline: 19089222] [doi: 10.1590/S1678-77572008000300011]

25. Baer PN, Wertheimer FW. A Histologic Study of the Effects of Several Periodontal Dressings on Periosteal-covered and Denuded Bone. J of Dent Res. 1961 Jul; 40(4):858. [doi: 10.1177/00220345610400041401]

26. Wennberg A, Mjör IA. Short term implantation studies of periodontal dressings. J Periodontal Res. 1983 May;18(3): 306-10. [Medline: 6225858] [doi: 10.1111/j.1600-0765.1983.tb00364.x]

27. Haugen E, Mjör IA. Bone tissue reactions to periodontal dressings. J Periodontal Res. 1979 Jan;14(1):76-85. [Medline: 153964] [doi: 10.1111/j.1600-0765.1979.tb00220.x]

28. Petelin M, Pavlica Z, Batista U, Stiblar-Martincic D, Skaleric U. Effects of periodontal dressings on fibroblasts and gingival wound healing in dogs. Acta Vet Hung. 2004;52(1):33-46. [Medline: 15119785] [doi: 10.1556/AVet.52.2004.1.4]

29. Haugen E, Hensten-Pettersen A. In vitro cytotoxicity of periodontal dressings. J Dent Res. 1978 Mar;57(3):495-9. [Medline: 79582] [doi: 10.1177/00220345780570031701]

30. Haugen E, Hensten-Pettersen A. Evaluation of periodontal dressings by hemolysis and oral LD50 tests. J Dent Res. 1979 Sep;58(9):1912-3. [Medline: 290657] [doi: 10.1177/00220345790580091301]

31. Spangberg L, Langeland K. Biologic effects of dental materials. 1. Toxicity of root canal filling materials on HeLa cells in vitro. Oral Surg Oral Med Oral Pathol. 1973 Mar;35(3):402-14 [Medline: 4510611] [doi: 10.1016/0030-4220(73)90078-9]

32. Dixon CM, Rickert VG. Tissue tolerance to foreign materials. J Am Dent Assoc. 1933;20:1458-72.

33. Guttuso J. Histopathologic study of rat connective tissue responses to endodontic materials. Oral Surg Oral Med Oral Pathol. 1963 Jun;16:713-27. [Medline: 13951493] [doi: 10.5301/jabfm.5000215]

34. Alpar B, Günay H, Geurtsen W, Leyhausen G. Cytocompatibility of periodontal dressing materials in fibroblast and primary human osteoblast-like cultures. Clin Oral Investig. 1999 Mar;3(1):41-8. [Medline: 10522192] [doi: $10.1007 / \mathrm{s} 007840050077]$

35. Hildebrand CN, DeRenzis FA. Effect of periodontal dressings on fibroblasts in vitro. J Periodontal Res. 1974;9(2):114-20. [Medline: 4277458] [doi: 10.1111/j.1600-0765.1974.tb00662.x]

36. Gilbert AD, Lloyd CH, Scrimgeour SN. The effect of a light-cured periodontal dressing material on HeLa cells and fibroblasts in vitro. J Periodontol. 1994 Apr;65(4):324-9. [Medline: $\underline{8195976]}$ [doi: 10.1902/jop.1994.65.4.324]

37. Cook JA, Mitchell JB. Viability measurements in mammalian cell systems. Anal Biochem. 1989 May 15;179(1):1-7. [Medline: 2667390] [doi: 10.1016/0003-2697(89)90191-7] 
38. Geurtsen W, Spahl W, Leyhausen G. Residual monomer/additive release and variability in cytotoxicity of lightcuring glass-ionomer cements and compomers. J Dent Res. 1998 Dec;77(12):2012-9. [Medline: 9839790] [doi: 10.1177/00220345980770121001]

39. Poulsom RC. An anaphylactoid reaction to periodontal surgical dressing: report of case. J Am Dent Assoc. 1974 Oct; 89(4):895-6. [Medline: 4529314] [doi: 10.14219/jada.archive.1974.0520]

40. Modena KC, Casas-Apayco LC, Atta MT, Costa CA, Hebling J, Sipert CR, Navarro MF, Santos CF. Cytotoxicity and biocompatibility of direct and indirect pulp capping materials. J Appl Oral Sci. 2009 Nov-Dec;17(6):544-54. [Medline: 20027424] [PMC free article: 4327511] [doi: 10.1590/S1678-77572009000600002]

41. Moharamzadeh K, Van Noort R, Brook IM, Scutt AM. Cytotoxicity of resin monomers on human gingival fibroblasts and HaCaT keratinocytes. Dent Mater. 2007 Jan;23(1):40-4. [Medline: 16426672] [doi: 10.1016/j.dental.2005.11.039]

42. Selimović-Dragaš M, Huseinbegović A, Kobašlija S, Hatibović-Kofman S. A comparison of the in vitro cytotoxicity of conventional and resin modified glass ionomer cements. Bosn J Basic Med Sci. 2012 Nov;12(4):273-8. [Medline: 23198945] [PMC free article: 4362505]

43. Baghani Z, Kadkhodazadeh M. Periodontal dressing: a review article. J Dent Res Dent Clin Dent Prospects. 2013 Fall;7(4):183-91. [Medline: 24578815] [doi: 10.5681/joddd.2013.040]

\section{To cite this article:}

Kadkhodazadeh M, Baghani Z, Torshabi M, Basirat B.

In Vitro Comparison of Biological Effects of Coe-Pak and Reso-Pac Periodontal Dressings

J Oral Maxillofac Res 2017;8(1):e3

URL: http://www.ejomr.org/JOMR/archives/2017/1/e3/v8n1e3.pdf

doi: $10.5037 /$ jomr.2017.8103

Copyright (C) Kadkhodazadeh M, Baghani Z, Torshabi M, Basirat B. Published in the JOURNAL OF ORAL \& MAXILLOFACIAL RESEARCH (http://www.ejomr.org), 31 March 2017.

This is an open-access article, first published in the JOURNAL OF ORAL \& MAXILLOFACIAL RESEARCH, distributed under the terms of the Creative Commons Attribution-Noncommercial-No Derivative Works 3.0 Unported License, which permits unrestricted non-commercial use, distribution, and reproduction in any medium, provided the original work and is properly cited. The copyright, license information and link to the original publication on (http://www.ejomr.org) must be included. 